\title{
Clinical and Prognostic Evaluation of Myelin Oligodendrocyte Glycoprotein Autoimmunity in the Central Nervous System
}

Merkezi Sinir Sisteminde Miyelin Oligodendrosit Glikoprotein Otoimmünitesinin Klinik ve Prognostik Açıdan Değerlendirilmesi

\author{
(1) Volkan Taşdemir, (1) Murat Kürtüncü \\ Istanbul University Istanbul Faculty of Medicine, Department of Neurology, Istanbul, Turkey
}

Keywords: Anti-MOG, neuromyelitis optica, autoimmunity, demyelinating diseases

Anahtar Kelimeler: Anti-MOG, nöromiyelitis optika, otoimmünite, demiyelinizan hastalıklar

Clinical and Prognostic Evaluation of Myelin Oligodendrocyte Glycoprotein Autoimmunity in the Central Nervous System

In $10-50 \%$ of patients with neuromyelitis optica (NMO) spectrum disease, anti-aquaporin 4 (anti-AQP4) antibody is observed to be negative (1). Anti-myelin oligodendrocyte glycoprotein (anti-MOG) antibodies are found in some of the antiAQP4 seronegative patients with NMO. MOG is found on the outer surface of the myelin sheath and in the oligodendrocyte plasma membrane, and is an important surface marker for oligodendrocyte maturation, although it constitutes only $0.05 \%$ of the myelin (2). Anti-MOG antibodies have been shown in pediatric acute disseminated encephalomyelitis, anti-AQP4 negative NMO, and multiple sclerosis.

Cobo-Calvo et al. (3) investigated the clinical spectrum and prognosis of adult patients with MOG antibodies in their article entitled, 'Clinical spectrum and prognostic value of CNS: MOG autoimmunity in adolescents (MOGADOR)', which was published in Neurology. According to data from the national NMO and associated diseases database in France between 2014 and 2017, 197 patients with anti-MOG antibodies over the age of 18 years were included in the study. Anti-AQP4 antibodies were not detected in any of these patients. The mean age of the patients was 36.5 (range: 18.0-76.8) years, and the sex distribution among the patients was also equal. The initial finding in $61 \%$ of the patients was optic neuritis, which was observed to be bilateral in $41 \%$ of patients. This finding was followed by myelitis (22.3\%), brain stem involvement (4.1\%), isolated encephalopathy (2.5\%), and combinations thereof. Oligoclonal bands were found in only $5.7 \%$ of patients and $44.2 \%$ had pleocytosis in their cerebrospinal fluid (CSF).

In the study, relapse occurred in $42.1 \%$ of patients in an average of 16 months. The attack risk reached $44.8 \%$ after 2 years and $61.8 \%$ after 5 years.

In a study in which magnetic resonance imaging of 108 patients with anti-MOG antibodies was evaluated, no significant difference in terms of radiologic features was observed between patients with anti-MOG antibodies and those with antiAQP4 antibodies. Lesions in the thalamus and pons were more frequent in patients with anti-MOG antibodies, whereas lesions in medulla oblongata and area postrema were more frequent in patients with anti-AQP4 antibodies. This situation was explained by increased antigen expression in the mentioned areas.

The risk of first attack was lower in patients with anti-MOG antibodies compared with patients with anti-AQP4 antibodies (Hazard ratio: $0.45,95 \%$ confidence interval: 0.26-0.79; $\mathrm{p}=0.005$ ).

Anti-MOG antibody titers, which were investigated in different periods, were much higher in the period of attack than in the period of remission. In addition, anti-MOG antibody titers in patients with monophasic disease were found to be lower than in patients with relapsing disease.

GFAP, an indicator of astrocyte damage, was increased in patients with anti-AQP4 antibodies, whereas it was not increased in patients with anti-MOG antibodies, which suggested that

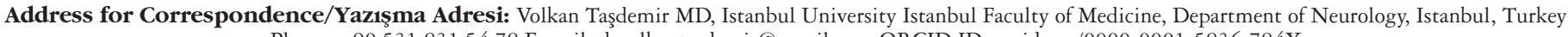
Phone: +90 5318315478 E-mail: drvolkantasdemir@gmail.com ORCID ID: orcid.org/0000-0001-5836-784X

Received/Geliş Tarihi: 19.06.2018 Accepted/Kabul Tarihi: 02.09.2018

${ }^{\circ}$ Copyright 2018 by Turkish Neurological Society

Turkish Journal of Neurology published by Galenos Publishing House. 
astrocyte damage was absent or less in patients with anti-MOG antibodies (4). The MOGADOR study highlighted that patients with anti-MOG antibodies had better outcomes compared with patients with anti-AQP4 antibodies.

In summary, 197 patients with anti-MOG antibodies were evaluated through clinical, radiologic, and CSF findings and were compared with patients with anti-AQP4 antibodies. It was noted that diseases with anti-MOG and anti-AQP4 antibodies were different from each other and anti-MOG antibody positivity had a positive effect on prognosis.

\section{References}

1. Jarius S, Wildemann B. Aquaporin-4 antibodies (NMO-IgG) as a serological marker of neuromyelitis optica: a critical review of the literature. Brain Pathol 2013;23:661-683.

2. Johns TG, Bernard CC. The structure and function of myelin oligodendrocyte glycoprotein. J Neurochem 1999;72:1-9.

3. Cobo-Calvo A, Ruiz A, Maillart E, at al; OFSEP and NOMADMUS Study Group. Clinical spectrum and prognostic value of CNS MOG autoimmunity in adults: The MOGADOR study. Neurology 2018;90:e1858-e1869.

4. Kaneko K, Sato DK, Nakashima I, et al. Myelin injury without astrocytopathy in neuroinflammatory disorders with MOG antibodies. J Neurol Neurosurg Psychiatry 2016;87:1257-1259. 